\title{
Regioselective Pd-catalyzed direct C1- and C2-arylations of lilolidine for the access to 5,6-dihydropyrrolo[3,2,1-ij]quino- line derivatives
}

\author{
Hai-Yun Huang, Haoran Li, Thierry Roisnel, Jean-François Soulé* and Henri Doucet ${ }^{\star} \S$
}

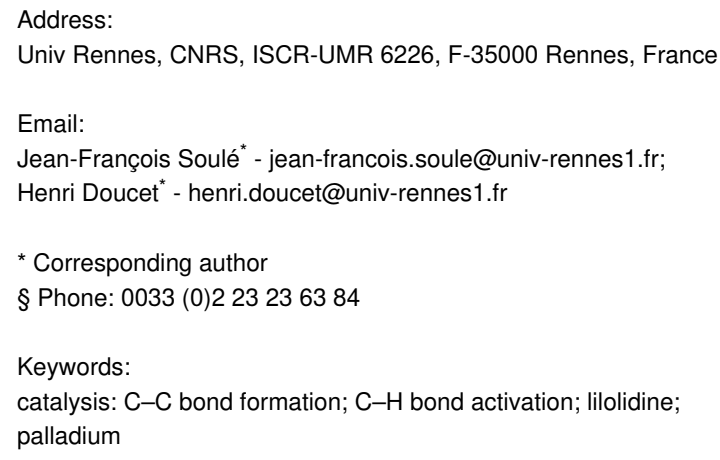

\author{
Beilstein J. Org. Chem. 2019, 15, 2069-2075. \\ doi:10.3762/bjoc. 15.204 \\ Received: 04 June 2019 \\ Accepted: 14 August 2019 \\ Published: 29 August 2019 \\ Associate Editor: K. Itami \\ (C) 2019 Huang et al.; licensee Beilstein-Institut. \\ License and terms: see end of document.
}

\begin{abstract}
The Pd-catalyzed $\mathrm{C}-\mathrm{H}$ bond functionalization of lilolidine was investigated. The use of a palladium-diphosphine catalyst associated to acetate bases in DMA was found to promote the regioselective arylation at $\alpha$-position of the nitrogen atom of lilolidine with a wide variety of aryl bromides. From these $\alpha$-arylated lilolidines, a second arylation at the $\beta$-position gives the access to $\alpha, \beta$-diarylated lilolidines containing two different aryl groups. The one pot access to $\alpha, \beta$-diarylated lilolidines with two identical aryl groups is also possible by using a larger amount of aryl bromide. The synthesis of 5,6-dihydrodibenzo[ $a, c]$ pyrido[3,2,1-jk]carbazoles from lilolidine via three successive direct arylations is also described. Therefore, this methodology provides a straightforward access to several lilolidine derivatives from commercially available compounds via one, two or three $\mathrm{C}-\mathrm{H}$ bond functionalization steps allowing to tune their biological properties.
\end{abstract}

\section{Introduction}

Lilolidine (Figure 1, left), which is a commercially available compound, contains a 5,6-dihydropyrrolo[3,2,1-ij]quinoline skeleton found in several bioactive molecules. For example, tivantinib (Figure 1, middle) exhibits MET inhibitor properties [1]; whereas tarazepide (Figure 1, right) is being investigated for the treatment of gastrointestinal diseases. Other lilolidine derivatives also exhibit properties for the treatment of cancers [2-5]. Therefore, the discovery of simple methods for the prepa- ration of lilolidine derivatives is an important research area in pharmaceutical chemistry.

To the best of our knowledge, so far only a few methods allow the synthesis of lilolidines arylated at $\alpha-[6,7]$ or $\beta$ - [8-13] positions of the nitrogen atom. In 2014, Chen and Tang et al. reported that $\mathrm{NH}_{4} \mathrm{PF}_{6}$ promotes the cyclodehydration of $\alpha$-aminocarbonyl compounds, leading to the formation of 
<smiles>c1cc2c3c(c1)ccn3CCC2</smiles>

lilolidine (5,6-dihydro-4H pyrrolo[3,2,1ij]quinoline)<smiles>O=C1NC(=O)[C@H](c2cn3c4c(cccc24)CCC3)[C@H]1c1c[nH]c2ccccc12</smiles><smiles>CN1C(=O)C(NC(=O)c2cc3cccc4c3n2CCC4)N=C(c2ccccc2)c2ccccc21</smiles>

Figure 1: Structures of lilolidine, tivantinib and tarazepide.

$\beta$-arylated 5,6-dihydropyrrolo[3,2,1-ij]quinoline derivatives [6] (Scheme 1a). Three $\alpha$-arylated 5,6-dihydropyrrolo[3,2,1$i j$ ]quinoline derivatives have been prepared by Pal et al. via the cyclization of 8-arylethynyl-1,2,3,4-tetrahydroquinolines [9] (Scheme 1b). The best results were obtained using $10 \mathrm{~mol} \%$ of $\mathrm{CuI}$ as catalyst in DMF at $100{ }^{\circ} \mathrm{C}$.

The late stage $\mathrm{C}-\mathrm{H}$ bond functionalization of molecules represents a powerful method for the easy screening of the biological properties of compounds containing a bioactive unit. Since the seminal work by Ohta et al. on the Pd-catalyzed C-H bond functionalization of heteroarenes such as thiophenes, furans, pyrroles and indoles $[14,15]$, this methodology has been widely applied for the preparation of new aryl-substituted heteroarenes [16-21]. Several results dealing with the $\mathrm{C}-\mathrm{H}$ bond functionalization of indoles have been reported allowing to prepare either $\alpha$ - [22-31] or $\beta$-arylated [32-37] indoles, depending on the reaction conditions. However, to the best of our knowledge, no example of regioselective $\alpha$ - or $\beta$-arylations via the $\mathrm{C}-\mathrm{H}$ bond functionalization of lilolidine has been reported so far (Scheme 1c).

Herein, we report i) on the simple access to $\alpha$-arylated 5,6dihydropyrrolo[3,2,1-ij]quinolines using an air-stable Pd cata-

\section{previous work}

a)<smiles>O=C(Br)CN1CCCc2ccccc21</smiles>

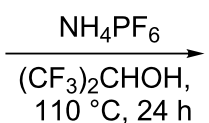<smiles>Brc1cn2c3c(cccc13)CCC2</smiles>

13 examples $53-95 \%$

b)<smiles>NC1NCCCc2cc(Br)cc(C#CBr)c21</smiles>

\section{$\underset{\text { DMF, } 100^{\circ} \mathrm{C} \text {, }}{\stackrel{\text { Cul } 10 \mathrm{~mol} \%}{\longrightarrow}}$} $12-18 \mathrm{~h}$<smiles></smiles>

3 examples $70-92 \%$

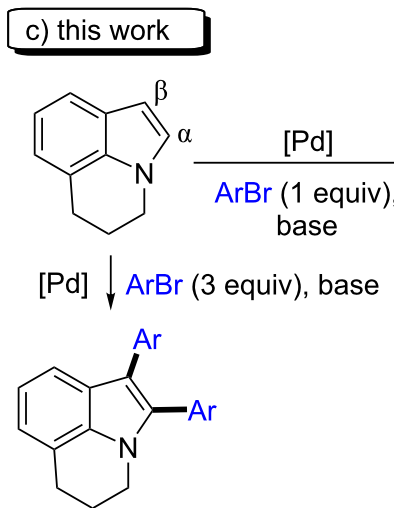

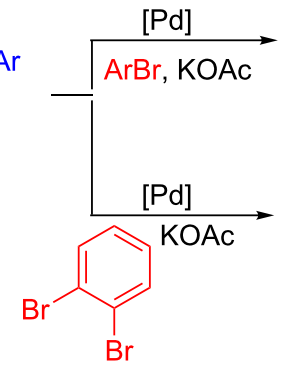

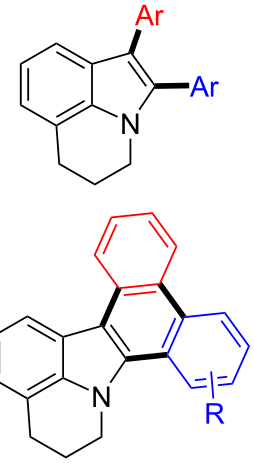


lyst associated to an inexpensive base, ii) on the sequential access to $\alpha, \beta$-diarylated 5,6-dihydropyrrolo[3,2,1-ij]quinolines containing identical or different aryl groups at $\alpha$ - and $\beta$-positions via two-fold $\mathrm{Pd}$-catalyzed $\mathrm{C}-\mathrm{H}$ bond functionalizations, iii) on the synthesis of 5,6-dihydrodibenzo[ $a, c]$ pyrido[3,2,1$j k$ ]carbazoles via three successive $\mathrm{C}-\mathrm{H}$ bond functionalization steps (Scheme 1c).

\section{Results and Discussion}

Based on our previous results on the arylation of heteroaromatics [38], we initially employed $1 \mathrm{~mol} \% \mathrm{Pd}(\mathrm{OAc})_{2}$ catalyst associated to $\mathrm{KOAc}$ as the base in DMA at $150{ }^{\circ} \mathrm{C}$ as the reaction conditions to promote the coupling of lilolidine with 3-bromobenzonitrile (Table 1, entry 1). Under these conditions a mixture of the $\alpha$-and $\beta$-arylated lilolidines $\mathbf{1 a}$ and $\mathbf{1 b}$ was obtained in a 64:36 ratio. Then, the influence of some bases on the regioselectivity with $\mathrm{Pd}(\mathrm{OAc})_{2}$ catalyst was examined. With CsOAc a similar regioselectivity than with KOAc was obtained, whereas the use of $\mathrm{NaOAc}$ afforded the products $\mathbf{1 a}$ and $\mathbf{1 b}$ in an 85:15 ratio, but with a moderate conversion of 3-bromobenzonitrile (Table 1, entries 2 and 3). High regioselectivities in favor of isomer 1a (85-90\%) were also obtained using $\mathrm{K}_{2} \mathrm{CO}_{3}$ and $\mathrm{Na}_{2} \mathrm{CO}_{3}$, but partial conversions of 3-bromobenzonitrile were observed (Table 1, entries 4-6). In order to improve the conversions of the aryl bromide, the thermally more stable $\mathrm{PdCl}\left(\mathrm{C}_{3} \mathrm{H}_{5}\right)(\mathrm{dppb})$ catalyst [39] was employed. With $\mathrm{K}_{2} \mathrm{CO}_{3}$ and $\mathrm{Na}_{2} \mathrm{CO}_{3}$, the conversion of 3-bromobenzonitrile was not improved, whereas using $\mathrm{NaOAc}$, a complete conversion of the aryl bromide was observed (Table 1, entries 8-10). Moreover, the regioselectivity in favor of $\alpha$-arylated lilolidine was improved to $93 \%$ affording $1 \mathrm{a}$ in $83 \%$ yield. The use of KOAc associated to $\mathrm{PdCl}\left(\mathrm{C}_{3} \mathrm{H}_{5}\right)(\mathrm{dppb})$ catalyst also afforded the regioisomer 1a in a quite good regioselectivity and yield (Table 1, entry 11). The higher conversions observed in the presence of acetate bases compared to carbonate bases (Table 1, entries 4-6 and 8-11) might be due to an easier coordination of acetates to palladium which favors the concerted metallation deprotonation (CMD) mechanism [40]. The regioselectivities observed using acetate bases are consistent with a CMD mechanism.

Then, a set of aryl bromides was reacted with lilolidine using 2 mol \% of $\mathrm{PdCl}\left(\mathrm{C}_{3} \mathrm{H}_{5}\right)(\mathrm{dppb})$ catalyst, $\mathrm{NaOAc}$ or $\mathrm{KOAc}$ as bases in DMA at $150{ }^{\circ} \mathrm{C}$ (Scheme 2). We initially studied the reactivity of electron-deficient aryl bromides. Acetyl, propionyl, benzoyl and ester as para-substituents on the aryl bromides were tolerated affording the target products $\mathbf{2}-\mathbf{6}$ in $64-77 \%$

Table 1: Influence of the reaction conditions on the palladium-catalyzed direct coupling of lilolidine with 3 -bromobenzonitrile. ${ }^{a}$

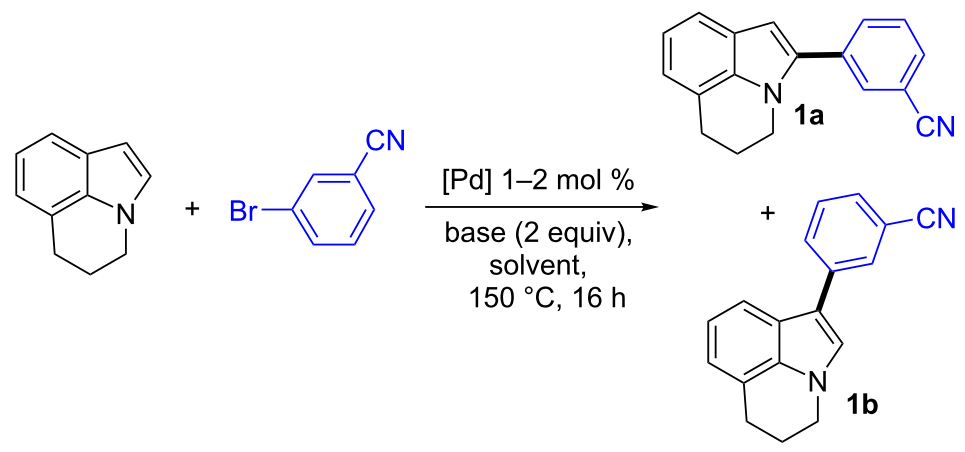

\begin{tabular}{|c|c|c|c|c|c|}
\hline Entry & Catalyst (mol \%) & Base & Conv. (\%) & Ratio 1a:1b & $\begin{array}{l}\text { Yield in } \\
\mathbf{1 a}(\%)\end{array}$ \\
\hline 1 & $\mathrm{Pd}(\mathrm{OAc})_{2}(1)$ & KOAc & 100 & $64: 36$ & 63 \\
\hline 2 & $\mathrm{Pd}(\mathrm{OAc})_{2}(1)$ & $\mathrm{CsOAc}$ & 100 & $69: 31$ & 58 \\
\hline 3 & $\mathrm{Pd}(\mathrm{OAc})_{2}(1)$ & $\mathrm{NaOAc}$ & 65 & $85: 15$ & 43 \\
\hline 4 & $\mathrm{Pd}(\mathrm{OAc})_{2}(1)$ & $\mathrm{K}_{2} \mathrm{CO}_{3}$ & 40 & $90: 10$ & 37 \\
\hline 5 & $\mathrm{Pd}(\mathrm{OAc})_{2}(1)$ & $\mathrm{Cs}_{2} \mathrm{CO}_{3}$ & 0 & - & - \\
\hline 6 & $\mathrm{Pd}(\mathrm{OAc})_{2}(1)$ & $\mathrm{Na}_{2} \mathrm{CO}_{3}$ & 33 & $85: 15$ & n.d. \\
\hline 7 & $\mathrm{Pd}(\mathrm{OAc})_{2}(1)$ & $\mathrm{KOAc}$ & $0^{\mathrm{b}}$ & - & - \\
\hline 8 & $\mathrm{PdCl}\left(\mathrm{C}_{3} \mathrm{H}_{5}\right)(\mathrm{dppb})(2)$ & $\mathrm{K}_{2} \mathrm{CO}_{3}$ & 42 & $90: 10$ & n.d. \\
\hline 9 & $\mathrm{PdCl}\left(\mathrm{C}_{3} \mathrm{H}_{5}\right)(\mathrm{dppb})(2)$ & $\mathrm{Na}_{2} \mathrm{CO}_{3}$ & 35 & $91: 9$ & n.d. \\
\hline 10 & $\mathrm{PdCl}\left(\mathrm{C}_{3} \mathrm{H}_{5}\right)(\mathrm{dppb})(2)$ & $\mathrm{NaOAc}$ & 100 & $93: 7$ & 83 \\
\hline 11 & $\mathrm{PdCl}\left(\mathrm{C}_{3} \mathrm{H}_{5}\right)(\mathrm{dppb})(2)$ & KOAc & 100 & $82: 18$ & 68 \\
\hline
\end{tabular}

${ }^{\mathrm{a} C}$ Conditions: lilolidine (1.5 mmol), 3-bromobenzonitrile (1 mmol), base $(2 \mathrm{mmol})$, DMA, under argon, $16 \mathrm{~h}, 150{ }^{\circ} \mathrm{C}$, isolated yields. ${ }^{\mathrm{b}}$ In xylene. 


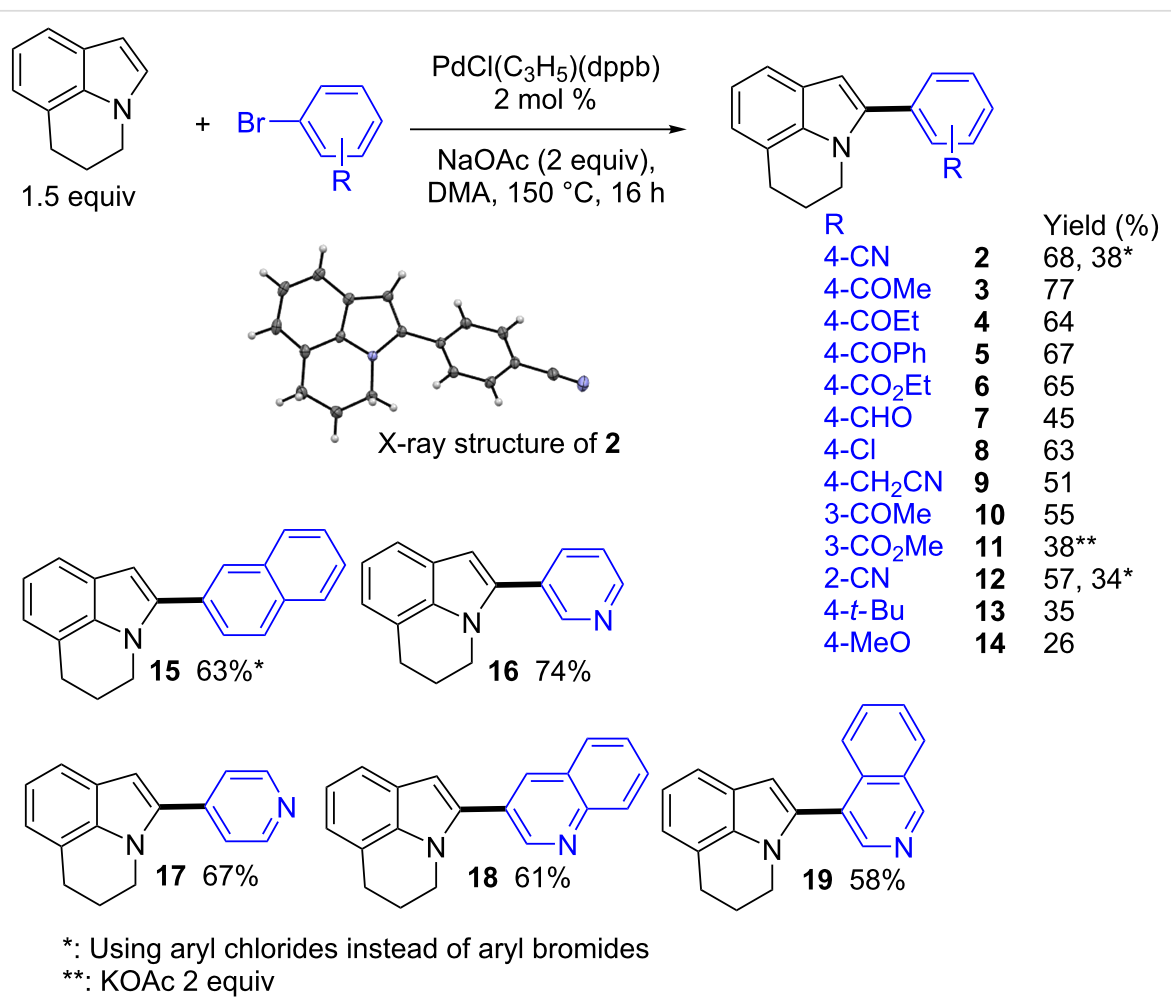

Scheme 2: Synthesis of $\alpha$-arylated lilolidine derivatives.

yields. The structure of $\mathbf{2}$ was confirmed by X-ray analysis. A lower yield of $\mathbf{7}$ was obtained for the reaction of 4-bromobenzaldehyde with lilolidine due to the formation of degradation products. Good yields in $\mathbf{8}$ and $\mathbf{9}$ were obtained from 4-chloroand 4-carbonitrile-substituted aryl bromides. In all cases, with these para-substituted aryl bromides, high regioselectivities in favor of the $\alpha$-arylations were observed. The meta-substituted 3-bromoacetophenone and methyl 3-bromobenzoate also afforded the $\alpha$-arylated lilolidines $\mathbf{1 0}$ and $\mathbf{1 1}$ with high regioselectivities. Conversely, with the more sterically hindered aryl source 2-bromobenzonitrile, a mixture of $\alpha$ - and $\beta$-arylated lilolidine derivatives was obtained (ratio $\alpha: \beta$ 69:31). The reactivity of two electron-rich aryl bromides was also examined. With 4-tert-butylbromobenzene and 4-bromoanisole, the target products 13 and 14 were obtained with high regioselectivities, but in low yields due to a partial conversion of these aryl bromides. It should be mentioned that the use of aryl chlorides instead of aryl bromides did not allow to improve the regioselectivities or the reaction yields. With 4-chlorobenzonitrile, product 2 was obtained in $80 \%$ regioselectivity and in $38 \%$ yield; whereas the use of 2-chlorobenzonitrile afforded $\mathbf{1 2}$ in $62 \%$ regioselectivity and in $34 \%$ yield. In both cases, partial conversions of the aryl chlorides were observed.

Pyridines and quinoline heterocycles are very important structures in pharmaceutical chemistry as more than 100 currently marketed drugs contain these units. Therefore, the reactivity of 3- and 4-bromo-substituted pyridines, 3-bromoquinoline and 4-bromoisoquinoline for the $\alpha$-arylation of lilolidine was also studied. In all cases, the desired $N$-containing coupling products 16-19 were obtained in high regioselectivities and in $58-74 \%$ yields.

Then, the one-pot synthesis of $\alpha, \beta$-di(hetero)arylated 5,6dihydropyrrolo[3,2,1-ij]quinolines was attempted (Scheme 3). The use of a larger amount of aryl bromides ( 3 equiv) provided the target diarylated lilolidines 20-22 in good yields. Under these conditions, the mono-arylated lilolidines were detected in very low yields by GC-MS analysis of the crude mixtures. The structure of $\mathbf{2 0}$ was confirmed by X-ray diffraction.

As $\alpha$-arylated lilolidines can be easily obtained under the reaction conditions shown in Scheme 2, the synthesis of $\alpha, \beta$-diarylated 5,6-dihydropyrrolo[3,2,1-ij]quinolines containing two different aryl groups at $\alpha$ - and $\beta$-positions via sequential Pd-catalyzed $\mathrm{C}-\mathrm{H}$ bond functionalization steps was studied (Scheme 4). The reaction of 1 equiv of 4-(5,6-dihydropyrrolo[3,2,1-ij]quinolin-2-yl)benzonitrile 2 and 1.5 equiv of a set of aryl bromides using again $2 \mathrm{~mol} \% \operatorname{PdCl}\left(\mathrm{C}_{3} \mathrm{H}_{5}\right)(\mathrm{dppb})$ catalyst associated to KOAc provided the desired diarylated lilolidines $\mathbf{2 3 - 2 6}$ in 55-87\% yields. The structure of $\mathbf{2 3}$ was confirmed by X-ray diffraction. 

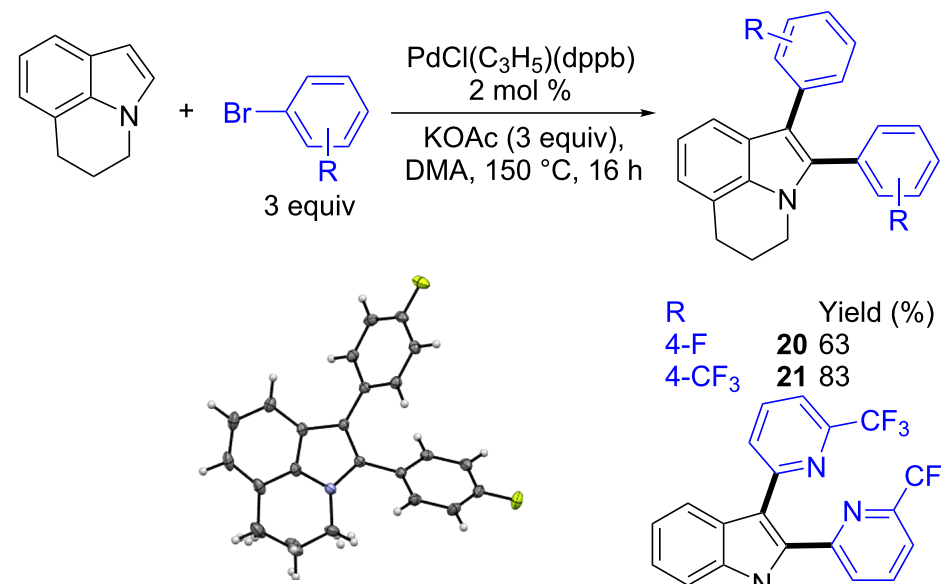

X-ray structure of $\mathbf{2 0}$

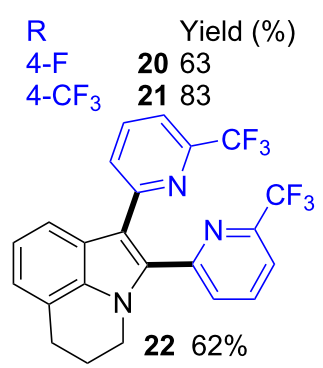

Scheme 3: Synthesis of $\alpha, \beta$-di(hetero)arylated lilolidine derivatives.<smiles>[R][I-]c1ccccc1Br</smiles>

quiv

1.5 equiv
$\mathrm{KOAC}$ ( 2 equiv), DMA, $150{ }^{\circ} \mathrm{C}, 16 \mathrm{~h}$

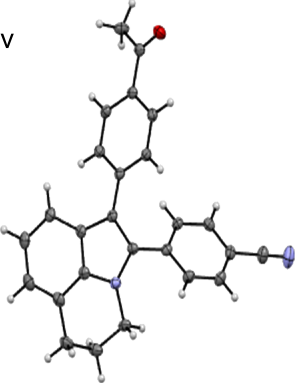

X-ray structure of 23

Scheme 4: Synthesis of $\alpha, \beta$-diarylated lilolidine derivatives via successive direct arylations.

Finally, the synthesis of 5,6-dihydrodibenzo[a,c]pyrido[3,2,1$j k]$ carbazoles via $\beta$-arylation of the previously obtained $\alpha$-arylated lilolidines followed by an intramolecular Pd-catalyzed direct arylation was examined (Scheme 5). The reaction of compound 2 with 1,2-dibromobenzene in the presence of $2 \mathrm{~mol} \% \mathrm{PdCl}\left(\mathrm{C}_{3} \mathrm{H}_{5}\right)(\mathrm{dppb})$ catalyst and $\mathrm{KOAc}$ as base afforded the desired carbazole 27 in moderate yield after $16 \mathrm{~h}$ due to a partial conversion of $\mathbf{2}$. However, the use of a longer reaction time $(48 \mathrm{~h})$ allowed to reach an almost complete conversion of $\mathbf{2}$, and the carbazole $\mathbf{2 7}$ was isolated in $62 \%$ yield. A slightly lower yield in the carbazole $\mathbf{2 8}$ was obtained from (4-(5,6dihydropyrrolo[3,2,1-ij]quinolin-2-yl)phenyl)(phenyl)methanone 5 and 1,2-dibromobenzene. This sequential C-H bond aryl-

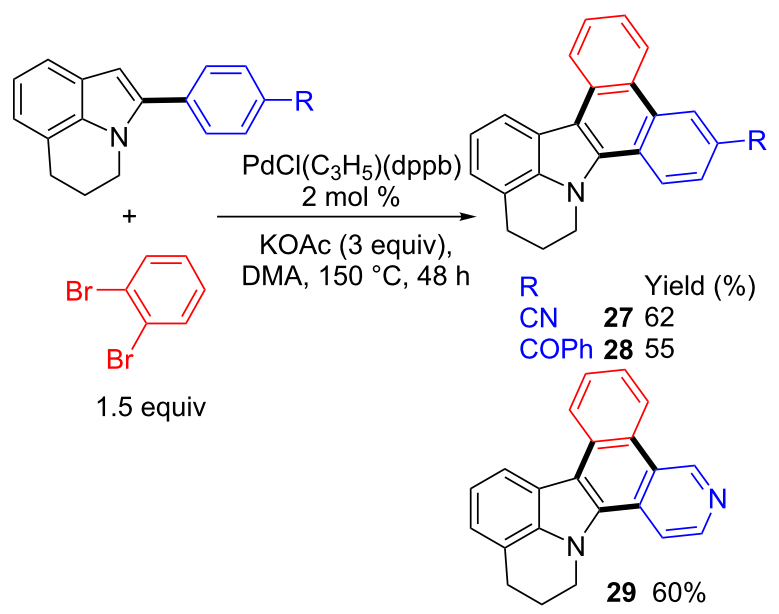

Scheme 5: Synthesis of 5,6-dihydrodibenzo[a,c]pyrido[3,2,1$j k]$ carbazoles via successive direct arylations.

ation strategy was also effective for the synthesis of the carbazole 29 from the pyridine $\alpha$-substituted lilolidine 17.

\section{Conclusion}

The late stage Pd-catalyzed $\mathrm{C}-\mathrm{H}$ bond functionalization allows to prepare (di)arylated lilolidine derivatives in only one or two steps. The $\alpha$-arylated lilolidines were generally obtained in high regioselectivities and in good yields using aryl bromides as easily available aryl sources, acetates as inexpensive bases and $\operatorname{PdCl}\left(\mathrm{C}_{3} \mathrm{H}_{5}\right)(\mathrm{dppb})$ as air-stable catalyst. The reaction tolerated a wide variety of useful functional groups such as nitrile, formyl, acetyl, propionyl, benzoyl, esters, chloro, or acetonitrile on the aryl bromide and the heteroaryl bromides 3- or 4-bromopyridines and 3-bromoquinoline. From these $\alpha$-arylated lilolidines, a second Pd-catalyzed direct arylation at $\beta$-position 
gave rise to $\alpha, \beta$-diarylated lilolidines with two different aryl units. The one pot access to $\alpha, \beta$-diarylated lilolidines with two identical aryl groups was also possible by using a larger amount of aryl bromide. The synthesis of 5,6-dihydrodibenzo $[a, c]$ pyrido[3,2,1-jk]carbazoles from lilolidine via three successive direct $\mathrm{C}-\mathrm{H}$ bond arylations also proceed nicely. Therefore, this methodology provides a straightforward access to a wide variety of $\alpha$ - and $\beta$-(hetero)aryl-substituted lilolidines allowing to tune or modify their biological properties.

\section{Supporting Information}

Supporting information features experimental procedures, products characterizations, copies of ${ }^{1} \mathrm{H}$ and ${ }^{13} \mathrm{C} \mathrm{NMR}$ spectra of all products and CCDC numbers of products $\mathbf{2}$, 20 and 23.

\section{Supporting Information File 1}

Experimental procedures and NMR spectra of compounds 1-29.

[https://www.beilstein-journals.org/bjoc/content/ supplementary/1860-5397-15-204-S1.pdf]

\section{Acknowledgments}

We thank China Scholarship Council for a fellowships to $\mathrm{HH}$ and HL.

\section{ORCID ${ }^{\circledR}$ iDs}

Thierry Roisnel - https://orcid.org/0000-0002-6088-4472 Jean-François Soulé - https://orcid.org/0000-0002-6593-1995 Henri Doucet - https://orcid.org/0000-0002-1410-3663

\section{References}

1. Remsing Rix, L. L.; Kuenzi, B. M.; Luo, Y.; Remily-Wood, E.; Kinose, F.; Wright, G.; Li, J.; Koomen, J. M.; Haura, E. B.; Lawrence, H. R.; Rix, U. ACS Chem. Biol. 2014, 9, 353-358. doi:10.1021/cb400660a

2. Huang, W.-S.; Li, F.; Dalgarno, D. C.; Gong, Y.; Ishchenko, A. V.; Kohlmann, A.; Shakespeare, W. C.; West, A. V.; Xu, Y.; Youngsaye, W.; Zhang, Y.; Zhou, T.; Zhu, X. Preparation of 2-anilino-4-heteroarylpyrimidine compounds for inhibition of mutant EGFR and mutant HER2 kinase. PCT Int. Appl. WO2015175632A1, Nov 19, 2015.

3. Wei, Y.; Li, Y.; Zhang, G.; Qui, G.; Hu, S.; Chen, L.; Li, S.; Zhang, Q. Preparation of (substituted phenyl) (substituted pyrimidine) amino deriv. as anticancer drugs. PCT Int. Appl. WO2016029839A1, March 3, 2016.

4. Zhu, Y.; Liu, Z.; Feng, C.; Hu, S.; Chen, H.; Bai, E.; Wang, J.; Shi, J. Deuterated 3-(4,5-substituted pyrimidinamine) phenyl derivative useful in treatment of cancer and its preparation. PCT Int. Appl. WO2018050108A1, March 22, 2018.
5. Zhang, H.; Wu, W.; Feng, C.; Liu, Z.; Bai, E.; Wang, X.; Lei, M.; Cheng, H.; Feng, H.; Shi, J.; Wang, J.; Zhang, Z.; Jin, T.; Chen, S.; Hu, S.; Zhu, Y. Eur. J. Med. Chem. 2017, 135, 12-23. doi:10.1016/j.ejmech.2017.04.036

6. Ji, X.-M.; Zhou, S.-J.; Deng, C.-L.; Chen, F.; Tang, R.-Y. RSC Adv. 2014, 4, 53837-53841. doi:10.1039/c4ra11168k

7. Ghorai, J.; Reddy, A. C. S.; Anbarasan, P. Chem. - Eur. J. 2016, 22 , 16042-16046. doi:10.1002/chem.201604111

8. Cao, C.; Shi, Y.; Odom, A. L. Org. Lett. 2002, 4, 2853-2856. doi:10.1021/ol0201052

9. Layek, M.; Dhanunjaya Rao, A. V.; Gajare, V.; Kalita, D.; Barange, D. K.; Islam, A.; Mukkanti, K.; Pal, M. Tetrahedron Lett. 2009, 50, 4878-4881. doi:10.1016/j.tetlet.2009.06.041

10. Wang, C.; Huang, Y. Org. Lett. 2013, 15, 5294-5297. doi:10.1021/ol402523x

11. Wang, J.; Wang, M.; Chen, K.; Zha, S.; Song, C.; Zhu, J. Org. Lett. 2016, 18, 1178-1181. doi:10.1021/acs.orglett.6b00310

12. Panferova, L. I.; Smirnov, V. O.; Levin, V. V.; Kokorekin, V. A.; Struchkova, M. I.; Dilman, A. D. J. Org. Chem. 2017, 82, 745-753. doi:10.1021/acs.joc.6b02344

13. Xu, C.; Xu, J. J. Org. Chem. 2018, 83, 14733-14742. doi:10.1021/acs.joc.8b02203

14. Akita, Y.; Inoue, A.; Yamamoto, K.; Ohta, A.; Kurihara, T.; Shimizu, M. Heterocycles 1985, 23, 2327-2333. doi:10.3987/r-1985-09-2327

15. Ohta, A.; Akita, Y.; Ohkuwa, T.; Chiba, M.; Fukunaga, R.; Miyafuji, A.; Nakata, T.; Tani, N.; Aoyagi, Y. Heterocycles 1990, 31, 1951-1958. doi:10.3987/com-90-5467

16. Satoh, T.; Miura, M. Chem. Lett. 2007, 36, 200-205. doi:10.1246/cl.2007.200

17. Bellina, F.; Rossi, R. Tetrahedron 2009, 65, 10269-10310. doi:10.1016/j.tet.2009.10.015

18. Ackermann, L.; Vicente, R.; Kapdi, A. Angew. Chem., Int. Ed. 2009, 48, 9792-9826. doi:10.1002/anie.200902996

19. Rossi, R.; Bellina, F.; Lessi, M.; Manzini, C. Adv. Synth. Catal. 2014, 356, 17-117. doi:10.1002/adsc.201300922

20. Gensch, T.; James, M. J.; Dalton, T.; Glorius, F. Angew. Chem., Int. Ed. 2018, 57, 2296-2306. doi:10.1002/anie.201710377

21. Mao, S.; Li, H.; Shi, X.; Soulé, J.-F.; Doucet, H. ChemCatChem 2019, 11, 269-286. doi:10.1002/cctc.201801448

22. Wang, X.; Gribkov, D. V.; Sames, D. J. Org. Chem. 2007, 72, 1476-1479. doi:10.1021/jo061979v

23. Bellina, F.; Calandri, C.; Cauteruccio, S.; Rossi, R. Tetrahedron 2007, 63, 1970-1980. doi:10.1016/j.tet.2006.12.068

24. Yang, S.-D.; Sun, C.-L.; Fang, Z.; Li, B.-J.; Li, Y.-Z.; Shi, Z.-J. Angew. Chem., Int. Ed. 2008, 47, 1473-1476. doi:10.1002/anie.200704619

25. Zhao, J.; Zhang, Y.; Cheng, K. J. Org. Chem. 2008, 73, 7428-7431. doi:10.1021/j0801371w

26. Joucla, L.; Batail, N.; Djakovitch, L. Adv. Synth. Catal. 2010, 352, 2929-2936. doi:10.1002/adsc.201000512

27. Liang, Z.; Yao, B.; Zhang, Y. Org. Lett. 2010, 12, 3185-3187. doi:10.1021/ol101147b

28. Zhou, J.; Hu, P.; Zhang, M.; Huang, S.; Wang, M.; Su, W. Chem. - Eur. J. 2010, 16, 5876-5881. doi:10.1002/chem.201000529

29. Wang, L.; Yi, W.-b.; Cai, C. Chem. Commun. 2011, 47, 806-808. doi:10.1039/c0cc01666g

30. Lu, G.-p.; Cai, C. Synlett 2012, 23, 2992-2996. doi:10.1055/s-0032-1317702 
31. Wu, M.; Luo, J.; Xiao, F.; Zhang, S.; Deng, G.-J.; Luo, H.-A.

Adv. Synth. Catal. 2012, 354, 335-340. doi:10.1002/adsc.201100603

32. Akita, Y.; Itagaki, Y.; Takizawa, S.; Ohta, A. Chem. Pharm. Bull. 1989, 37, 1477-1480. doi:10.1248/cpb.37.1477

33. Zhang, Z.; Hu, Z.; Yu, Z.; Lei, P.; Chi, H.; Wang, Y.; He, R. Tetrahedron Lett. 2007, 48, 2415-2419. doi:10.1016/j.tetlet.2007.01.173

34. Cusati, G.; Djakovitch, L. Tetrahedron Lett. 2008, 49, 2499-2502. doi:10.1016/j.tetlet.2008.02.130

35. Bellina, F.; Benelli, F.; Rossi, R. J. Org. Chem. 2008, 73, 5529-5535. doi:10.1021/j08007572

36. Ackermann, L.; Barfüßer, S. Synlett 2009, 808-812. doi:10.1055/s-0028-1087951

37. Cornella, J.; Lu, P.; Larrosa, I. Org. Lett. 2009, 11, 5506-5509. doi:10.1021/ol902304n

38. Zhao, L.; Bruneau, C.; Doucet, H. ChemCatChem 2013, 5, 255-262. doi: $10.1002 /$ cctc. 201200521

39. Cantat, T.; Génin, E.; Giroud, C.; Meyer, G.; Jutand, A. J. Organomet. Chem. 2003, 687, 365-376. doi:10.1016/s0022-328x(03)00791-5

40. Potavathri, S.; Pereira, K. C.; Gorelsky, S. I.; Pike, A.; LeBris, A. P.; DeBoef, B. J. Am. Chem. Soc. 2010, 132, 14676-14681. doi:10.1021/ja107159b

\section{License and Terms}

This is an Open Access article under the terms of the Creative Commons Attribution License (http://creativecommons.org/licenses/by/4.0). Please note that the reuse, redistribution and reproduction in particular requires that the authors and source are credited.

The license is subject to the Beilstein Journal of Organic Chemistry terms and conditions:

(https://www.beilstein-journals.org/bjoc)

The definitive version of this article is the electronic one which can be found at:

$\underline{\text { doi:10.3762/bjoc. } 15.204}$ 